Joanna Karabin

Uniwersytet Śląski w Katowicach

\title{
Problemy integracyjne ludności napływowej na polskim Górnym Śląsku w okresie dwudziestolecia międzywojennego
}

Treść niniejszego artykułu stanowi zagadnienie integracji społecznej ludności napływowej z innych dzielnic państwa polskiego na obszarze pruskiego Górnego Śląska, włączonym następnie do polskiej Macierzy. Ramy chronologiczne wyznaczone są czasem istnienia II Rzeczypospolitej. Pojęciem integracji społecznej objęte zostały zagadnienia związane z procesem włączania się do górnośląskiego społeczeństwa różnorodnych grup społecznych i w konsekwencji uzyskania przez nie możliwości, praw i usług dotychczas dostępnych tylko rodzimej ludności. Proces ten nie był sprawą oczywistą, gdyż często oznaczał konieczność wyrzeczenia się przez jedną lub obie strony pełni lub części swojej tożsamości rozumianej jako wartości, normy, zwyczaje, tradycja, prawo, światopogląd, a nawet język. Złożony proces integracji społecznej był jednym z dystynktywnych trudności w tym regionie.

1. Przyczyny napływu i wzrost antagonizmu dzielnicowego Zakończenie I wojny światowej oznaczało dla ziem polskich powstanie niepodległego państwa. Tymczasem na Górnym Śląsku wszystko było prawie tak jak do tej pory. Niemieckie rządy, administracja, szkoły i urzędnicy. Położenie mieszkańców tego terenu doskonale przedstawia rozporządzanie landrata rejencji opolskiej, w skład której wchodził Górny Śląsk: „Wszelkie dążenia do oderwania Górnego Śląska od niemieckiej Rzeszy uznane zostaną za zdradę stanu"'. Mimo rozlicznych przeszkód mieszkańcy tego 
terenu ustawicznie dawali wyraz woli połączenia z państwem polskim. Niewątpliwie na wzrost dążeń narodowych wpłynęły wydarzenia w Poznańskiem, gdzie w grudniu 1918 r. przygotowało zryw przeciwko niemieckiemu panowaniu. Wraz z upływem czasu na Górny Śląsk zaczęła przybywać ludność z innych terenów nowopowstałego państwa polskiego. Nie da się ukryć, że napływ ten stymulowany był początkowo głównie przez czynniki ekonomiczne. Poszukiwania pracy i lepszego bytu determinowały osiedlanie się na tym obszarze. Dopiero potrzeby akcji plebiscytowej w 1921 r. spowodowały przybycie na Górny Śląsk licznej rzeszy polskich agitatorów pochodzących z byłego zaboru austriackiego. Wprawdzie ruch polski na Górnym Śląsku działał od lat 80. XIX w., jednak dla rodzimej ludności był to pierwszy tak szeroki i bezpośredni kontakt z inteligencją polską. Podkreślić należy, że w 1922 r. w polskiej grupie etnicznej społeczności Górnego Śląska, a następnie województwa śląskiego, nie było przedstawicieli klas posiadających - ziemiaństwa i mieszczaństwa, słabe było również drobnomieszczaństwo. Dominowały klasy plebejskie - robotnicy i chłopi. Pod względem zasobów rodzimej inteligencji głównie część górnośląska województwa odczuwała silny jej brak. Była ona potrzebna zarówno gospodarce, jak i administracji publicznej oraz szkolnictwu. Tymczasem od momentu przybycia dużej części agitatorów² zaczęły rodzić się wątpliwości, czy sprostają aspiracjom pokładanym w nich przez ludność Górnego Śląska.

Trzeba zaznaczać, że dla ówczesnej, jakże nielicznej śląskiej inteligencji reformy społeczne, socjalne przeprowadzane na drodze parlamentarnej, bez naruszenia porządku społecznego, stanowiły najwłaściwszą perspektywę. Tym niemniej inteligencja ta uświadamiała sobie konieczność współpracy z napływowymi, nie tylko inteligentami, ale i środowiskami robotniczymi. Próbowała przejąć na siebie nie tylko rolę krzewiciela oświaty i kultury, ale także budzenia i podtrzymywania wśród ludności świadomości narodowej, jak również zadanie przebudowy społeczeństwa według własnych koncepcji. Biorąc pod uwagę całokształt zjawisk społecznych i politycznych, jakie występowały w początkach XX wieku, zarysowane koncepcje odnowy społecznej nie mogły stać się zaczynem nowatorskich przeobrażeń. Po 1922 r. warunki dojrzały już do o wiele bardziej radykalnych 1921), Nauka dla wszystkich, PAN, t. 346, Wrocław 1981, s. 1-31. 
postaw, przed którymi jednak inteligencja na Śląsku wzbraniała się, dając tym samym pierwszeństwo w organizacji polskiego życia publicznego ludności napływowej.

Przyczyn ksenofobii dzielnicowej należy szukać w polityce władz pruskich, które podejmowały w stosunku do ludności śląskiej działania mające na celu wyrugowanie polskości, co miało odbić się na stosunkach społecznych i kulturalnych. Starano się uniemożliwić rozwój polskiej kultury i nie dopuszczać ludności polskiej do szkół i urzędów. Wobec duchowieństwa i stanu nauczycielskiego, a więc tej części ludności, która z racji wykształcenia miałaby możliwość szerszego oddziaływania na społeczeństwo, rząd pruski stosował szczególnie silne represje. Mimo że akcja germanizacyjna nie przyniosła oczekiwanych rezultatów, coraz wyraźniejszy stawał się podział społeczeństwa na bogatszą ludność niemiecką oraz pozbawioną własności i wpływów polską. Wobec tego mieszkańcy Górnego Śląska z pojęciem „inteligent" kojarzyli przedstawicieli narodowości niemieckiej. Toteż germanizacja była jednym z podstawowych czynników określających społeczną sytuację Górnego Śląska. W wyobrażeniu rodzimej ludności, jeżeli Ślązak dostał się do gimnazjum lub na uniwersytet, to zazwyczaj wracał zniemczony. Zrobił się "panoczkiem" w pojęciu ludności, inteligentem, który zarazem przekształcił się w Niemca ${ }^{3}$.

Paradoksalnie to właśnie presja germanizacyjna wywierana na ludność górnośląską uwydatniła problem poczucia przynależności narodowej. Jedna z opinii niemieckiego urzędnika w pełni oddawała tę zależność:

Wprawdzie na Górnym Śląsku, podobnie zresztą, jak i na rzeczywiście polskich ziemiach człowiek nie posługuje się pięknym językiem warstw wykształconych, jednakże włada on tym językiem jako mową potoczną dziesięć razy lepiej, niżeli niemiecki chłop w powiecie oleśnickim, na Pogórzu, czy podwrocławski zielarz językiem niemieckim (...). Głównymi przyczynami niskiego poziomu kultury była nie mowa polska, ale występujący dotychczas brak wykwalifikowanych nauczycieli $(. . .)^{4}$.

3 L. Aleksa, Inteligencja na Śląsku, Katowice 1975, s. 7, 11, 15. W połowie XIX w. jeden z przedstawicieli ówczesnej inteligencji określił ją następująco: „Ci wszyscy, co troskliwsze i rozleglejsze odebrawszy po szkołach wyższych i instytucjach wychowanie, stoją na czele narodu jako uczeni, urzędnicy, nauczyciele, duchowni, przemysłowcy, zgoła którzy nam przewodzą wskutek wyższej oświaty". L. Aleksa, Inteligencja..., op. cit., s. 12,14. 
W XIX w. na Górnym Śląsku ludność polska, mówiąca wyłącznie po polsku, to ludzie ubodzy, odsunięci od jakichkolwiek stanowisk ze względu na brak znajomości języka niemieckiego ${ }^{5}$.

Poczucie odradzającej się polskiej jedności narodowej wśród Górnoślązaków oraz różnice zachodzące pomiędzy Górnym Śląskiem a resztą Polski nie pozostawały bez wpływu na wzajemne stosunki społeczne poszczególnych grup ludności. I to zarówno inteligencji miejscowej i napływającej z innych regionów, jak i pozostałych klas i warstw społecznych. Z jednej strony istnieje poczucie własnej godności i wartości, potęgowane przez rolę, jaką Śląsk i jego praca odgrywają w życiu gospodarczym Polski, i równoczesna obawa niezrozumienia czy niedocenienia; z drugiej strony przejawiają się trudności w nawiązaniu porozumień, wynikające z odmienności rozwoju dziejowego i urobionych na tym podłożu przyzwyczajeń i urządzeń społecznych. Podczas badań jakichkolwiek form życia społecznego na Śląsku napotyka się nie tylko pewne faktyczne odrębności w stosunkach społecznych i towarzyskich, ale co ważniejsze, na charakterystyczną dążność utrzymania ich, dążność pozostawania w swoich kręgach społecznych ${ }^{6}$. Takie zachowanie odrębności w warunkach panowania obcego żywiołu było równoznaczne z walką o przetrwanie. Natomiast kontynuacja dążności do pozostawania we własnych kręgach społecznych w zetknięciu z ludnością polską spoza Śląska może być m.in. wyrazem utrwalonych już i obowiązujących w tym środowisku schematów więzi społecznych obwarowanych tradycją.

2. Wyznaczanie zadań społecznych polskiej inteligencji Skłonność do zachowania odrębności była charakterystyczna dla inteligencji górnośląskiej. Wynikało to także bardzo wyraźnie ze statutu założonego 7 sierpnia 1919 r. Śląskiego Związku Akademickiego ${ }^{8}$. W statucie tym, poza warunkami, jakie muszą spełniać kandydaci na członków, odnoszącymi się do narodowości, inteligencji napływowej z innych dzielnic Polski, stawia się warunek adaptacji do stosunków panujących na Śląsku i poznania tutejszych problemów. Co jednak nie przeszkadzało jego

\footnotetext{
$5 \quad$ L. Aleksa, Inteligencja..., op. cit., s. 12,14.

6 P. Rybicki, O badaniu socjograficznym Ślaska, Katowice 1938, s. 36.

7 L. Aleksa, Inteligencja..., op. cit.., s. 22. Zob. A. Tokarska, Książki, ludzie, idee. Kontakty kulturalne Górnego Śląska z Krakowem w dobie niewoli narodowej, Katowice 2003, s. 94-125.

$8 \quad$ "Katolik", nr 96 (1919), s. 2.
} 
działaczom formułować postulaty typu: „Nie ma stanu akademickiego, któryby nie znalazł pola do współpracy (...). Akademik powinien być nie tylko osobistością i społecznikiem, ale również pionierem polskiej myśli państwowej, powinien być przodującym obywatelem"9. Podkreślenie swej odrębności, a czasami nawet niechęci miejscowej ludności, również części inteligencji rodzimej wobec inteligencji napływowej były rezultatem nie tylko z uwarunkowań historycznych. Indywidualna postawa mieszkańców wobec przybyszów wynikała też z poczucia subiektywnie rozumianej "krzywdy”, gdyż pozycje i miejsca, do których niejako naturalne aspiracje żywili Ślązacy, zajmowane były przez „obcych". Prasa polska z tamtych lat, jak i formułowane przy różnych okazjach zadania dla inteligencji pozwalają stwierdzić, że w programie działania tej grupy nie było miejsca na rozwiązywanie podstawowych problemów wynikających z socjalnego układu społeczeństwa, mimo iż inteligencja dostrzegała potrzebę współpracy z robotnikami i chłopstwem. Świadomość ta była niewątpliwie konsekwencją chłopskiego i robotniczego pochodzenia inteligencji polskiej na Śląsku. Postulowano natomiast rozwiązywanie wszystkich problemów na drodze zorganizowania narodu i społeczeństwa w odpowiednie państwo ${ }^{10}$.

Dokumentem programowym, z którego można wnioskować o tendencjach panujących wśród polskiej inteligencji Górnego Śląska, jest referat wygłoszony przez ks. Teodora Kubinę (późniejszego biskupa częstochowskiego) na I Zjeździe Śląskich Akademików w sierpniu 1919 roku. Ks. T. Kubina wyraził pogląd, że wszelka praca społeczna winna dążyć do tego, by naród stał się społeczeństwem. Stanie się tak wówczas, gdy pojedyncze jednostki i pojedyncze warstwy zorganizują się w całość, będą wykonywać funkcje odpowiednie do swoich warunków życia na korzyść dobra całości państwa, narodu i na odwrót - całość państwa, naród stworzą im warunki zupełnego i wszechstronnego rozwoju dla zaspokojenia wszystkich potrzeb duszy i ciała, a więc wtedy, gdy będą one pracować pro bono publico, a państwo pro bono private. Ks. T. Kubina stwierdzał, że w tym momencie powstaje najważniejsze zadanie socjalne, szczególnie dla inteligencji - zadanie gruntownego, wszechstronnego i głębokiego studium kwestii socjalnej. Zdaniem ks. T. Kubiny należy wytężyć

9 E. Szramek, Śląsk jako problem socjologiczny, Katowice 1934, s. 56.

10 L. Aleksa, Inteligencja..., op. cit. 
wszelkie nasze siły duchowe, korzystać z naszej wiedzy, żeby znaleźć ów ustrój gospodarczy, owe formy społecznego życia i ducha społecznego, które by prowadziły do wytworzenia zdrowego społeczeństwa. Nie powinniśmy lekceważąco zbywać nowych haseł społecznych, nawet takich jak komunizm i bolszewizm, ale badać powinniśmy sumiennie i krytycznie bez uprzedzeń, czy w nich nie tkwi jaka siła zbawienna, czy czegoś z tych różnych systemów nie można przyjąć. Zachęcając do podejmowania postawionego przez siebie zadania, ks. T. Kubina uważał, że na Górnym Śląsku istniejące stosunki społeczne stwarzały pod pewnym względem korzystne sytuacje: „My na Górnym Śląsku jesteśmy pod tym względem szczęśliwsi niż w innych dzielnicach Polski. U nas nie ma antagonizmu, przynajmniej niewielkiego, między inteligencją a ludnością prostą"11, a to dlatego, że Ślązacy "akademicy" prawie wyłącznie pochodzili z ludu. Nie było także przeciwieństwa między szlachtą i ludem, a także między pracodawcami i pracownikami, bo nie było na Górnym Śląsku szlachty polskiej ani przynajmniej większych pracodawców. Inteligencja miała być powołana do ustanowienia w partiach rozsądnego programu społecznego. Ks. Kubina konkludował, że mamy niewątpliwie światłych robotników, światłych rolników, ale wiedza ich nie wystarczy dla tego niezmiernie ważnego zadania, jakim było rozwiązanie kwestii społecznej. Twierdził ponadto, że w żaden sposób nie powinniśmy się odsuwać od ludu, od robotników, od rolników, tylko stworzyć wspólnie z nimi własną, odrębną partię polityczną. Powinniśmy raczej wstępować w partie ludowe, partie robotników, rolników i w nich współpracować z szerokimi masami ludu. Program ten był oficjalnym dokumentem i w zasadzie jedynym formułującym wprost działania inteligencji. Ks. Kubina wskazał w nim zadania postępowe, czego do tej pory nie notowano w wystąpieniach osób duchownych ${ }^{12}$. Istotnie sprawy związane z inteligencją znajdywały swój wydźwięk już nie tylko na kolejnych zjazdach duchowieństwa ${ }^{13}$, ale także środowiska polityczne zdawały się odczuwać silną potrzebę współpracy z elitami napływowymi. Zaznaczono jednak, że wprawdzie inteligencja nie może stanowić specjalnej

11 M. Trąba, Ksiadz dr Teodor Kubina. Działalność społeczna $i$ narodowa w latach 1905-1925, Świętochłowice 2002, s. 166-167.

12 Ibidem. L. Aleksa, Inteligencja..., op. cit., s. 23-24.

13 L. Krzyżanowski, Spór o postawę religijna międzywojennej inteligencji na polskim Górnym Śląsku. Casus Tadeusza Starka, „Folia Historica Cracoviensia”, t. 3, nr 7 (2016), s. $98-99$. 
grupy społecznej, to musi spełnić rolę siły kierowniczej, której potrzebowały wszystkie stronnictwa polityczne ${ }^{14}$.

Alternatywny program integracji społecznej niosła za sobą przybywająca inteligencja pochodzenia galicyjskiego. Większość jej przedstawicieli wyznawała poglądy demokratyczne, ale w życiu przestrzegała zasad typowych dla przedstawicieli zdegradowanego środowiska szlachecko-ziemiańskiego. Dominujące w życiu Górnoślązaków zasady zapobiegliwości, gospodarności i pracowitości, a także bezpośredni sposób nawiązywania kontaktów z przedstawicielami grup wyżej położonych w hierarchii społecznej jej przedstawiciele odbierali jako obce cechy cywilizacyjne. Raził także plebejski etos inteligencji autochtonicznej. Konflikt z cieszącymi się uznaniem lokalnymi zwyczajami i sposobami wartościowania przypisywano ich obcemu, niemieckiemu pochodzeniu ${ }^{15}$. Jak sygnalizowano, napływowa ludność zajmowała wyższe w hierarchii społecznej stanowiska, w przeszłości zastrzeżone dla Niemców. Inaczej się zachowywali. Zachowanie to bardzo często było o wiele mniej egalitarne niż zachowanie przedstawicieli ludności niemieckiej. Takie postawy jasno implikowały trudności z integracją społeczną.

Napięcie na tle przynależności do różnych grup społecznych przybrało na sile w okresie oczekiwania na włączenie do Rzeczypospolitej przyznanej jej części Górnego Śląska. Niechęć była skierowana nawet ku tym Górnoślązakom, którzy w swej działalności korzystali z pomocy napływowych inteligentów. Od zarzutów nie był wolny prezes Naczelnej Rady Ludowej Józef Rymer. Oskarżono go o to, że otacza się różnymi panami spoza granicy Górnego Śląska, którzy nie znają tutejszych stosunków i psychologii Górnoślązaków. Obok pojawiającej się wrogości szczególnie drażniącym dla śląskich warstw plebejskich okazał się "pański styl" przybyłych ${ }^{16}$.

\section{Kościół katolicki wobec napływowych}

Z kolei przeszkodą dla przybyszy w akceptacji obyczajowej Górnego Śląska stała się nadmierna religijność jego mieszkańców. Intensywność przeżyć religijnych była u nich większa niż u stronników z innych województw. Zwrócił na to uwagę biskup katowicki Arkadiusz Lisiecki podczas przemówienia w marcu 1926 roku:

$14 \quad$ "Katolik", nr 109 (1922), s. 2.

15 E. Kopeć, My i oni na polskim Śląsku (1918-1939), Katowice 1993, s. 35.

16 E. Kopeć, My i oni..., op. cit., s. 30-31. 
O Was to Ślązacy mówią w całej Polsce naszej, że może wy właśnie jesteście najlepszą, najzdrowszą cząstką wielkiego Narodu naszego. Na was to kraj cały patrzy z podziwem, kiedy się buduje Waszą głęboką wiarą, Waszą miłością Boga i Ojczyzny ${ }^{17}$.

Biskup, będąc Wielkopolaninem, miał możliwość pełniej ocenić nowych diecezjan, bo czynił to z perspektywy przyjezdnego. Dla napływowych, choć w przeważającej mierze reprezentujących wyznanie rzymskokatolickie, czynnik religijny nie był tak eksponowany, jak to miało miejsce w przypadku mieszkańców Górnego Śląska, którym przybysze zarzucali zbyt manifestacyjne okazywanie wiary i przywiązanie do Kościoła. Na tle nietolerancyjnego pod względem wyznaniowym środowiska śląskiego znamienny był fakt łączenia przybyszy z działalnością sekt oraz innych związków religijnych. Ks. Jan Gajda z parafii św. Jadwigi w Chorzowie w liście do Kurii Biskupiej w Katowicach pisał:

Wśród odstępców są przeważnie ludzie, którzy już dawno zerwali z Kościołem, zawierając ślub mieszany coram ministro a catholico. Znajdują się miedzy nimi i tacy, którzy ślub mieszany zawarli w kościele katolickim, ale potem pod wpływem niekatolickiej strony z całą rodziną odpadli od niego. Daje się odczuć wpływ polskich ewangelików z Cieszyńskiego, którzy w tutejszych zakładach piastują poważne urzędy. 7 osób związało się z przybyłymi sekciarzami. W dwóch przypadkach wyprowadziła się dziewczyna do Niemiec, aby wyjść za mąż za nowopoganina ${ }^{18}$.

Dysonans w podejściu do wiary i religijności różnych grup społecznych Górnego Śląska pogłębiała polemika na łamach „Polaka”. W organie Narodowej Partii Robotniczej można było przeczytać, że "na zjazdach katolickich nie ma inteligencji, bo jej przedstawiciele są ateistami nie wierzącymi w Boga"19. Ludność napływową wiązano również ze Związkiem

17 L. Krzyżanowski, Ruchy migracyjne na Górnym Śląsku w XIX i w pierwszej połowie $X X$ w., a wielokulturowość tego obszaru w okresie międzywojennym, w: Procesy migracyjne: teoria, ewolucja i współczesność, L. Kacprzak, J. Knopek, Piła 2008, s. 283. Archiwum Archidiecezjalne w Katowicach (dalej: AAKat), Akta Lokalne (dalej: AL), sygn. 46/407, Chorzów. Parafia św. Jadwigi, tom II (1935-1978), k. 30. Do Kurii Biskupiej z dnia 19 kwietnia 1938 roku.

19 AAKat., Akta Rzeczowe (dalej: ARZ), sygn. 47/497, I Śląski Zjazd Katolicki (1922). „Polak" 19.09.1922 rok. Zjazd katolicki a inteligencja endecko-chadecka, k. 146. 
Wolnomyślicieli, który w połowie lat trzydziestych ożywił swoją działalność na Górnym Śląsku. Choć skupiał nieliczną grupę przedstawicieli inteligencji, poddawano go nieustannie inwigilacji ze strony władz państwowych, które na początku 1935 roku wytoczyły mu proces, zarzucając także jego członkom przynależność do Komunistycznej Partii Polskiº.

"Gorole, przybłędy i biurokraci" pisała „Polska Zachodnia" w 1933 roku.

Nie ma się co łudzić, fala niechęci rośnie, a w skutek ciężkiej sytuacji gospodarczej województwa, pewnych odrębności psychicznych tutejszej ludności, błędów, popełnianych przez niektórych przybyszów, a wreszcie i podjudzającej akcji ludzi przeciwdziałających świadomie zespoleniu duchowemu Śląska z Państwem Polskiem $^{21}$.

Dlatego też na XX posiedzeniu Dziekanów Diecezji Śląskiej, które odbyło się 19 grudnia 1927 roku ks. kanonik M. Lewek stwierdził: „Koniecznie trzeba znaleźć drogę do serc inteligencji, powinno się więcej pracować w kościołach niż na salach", aks. E. Szramek zauważył:

Za oporność i trudności, jakie się napotyka ze strony inteligencji napływowej odpowiada inteligencja tubylcza. Nie ma ona zrozumienia dla napływowej inteligencji i niegrzecznością okazuje im to nawet w kościele, a swoimi wypowiedziami tylko ich zraża ${ }^{22}$.

Faktem było, że często dochodziło także do zatargów pomiędzy duchownymi asystentami a zarządem Akcji Katolickiej w danej parafii. W tym przypadku główną przyczyną antagonizmów było ciągłe ingerowanie m.in. duchownych w pracę świeckich katolików ${ }^{23}$. Przedstawicielstwa tych ostatnich można było spotkać zazwyczaj wśród kierownictwa Akcji Katolickiej i innych organizacji oraz w radach parafialnych ${ }^{24}$.

Zob. M. Wanatowicz, Inteligencja na Śląsku w okresie międzywojennym, Katowice 1986, s. 70. Zob. F. Jaśkowiak, Województwo poznańskie. Szkic monograficzny, Poznań 1980, s. 47 E. Szramek, Śląsk..., op. cit., s. 30. AAKat., ARZ, sygn.47/251, Synod, tom I (1928-1935), k. 124. AAKat., ARZ, sygn. 47/603, Akcja Katolicka, tom I (1932-1936), k. 152.Bp S. Adamski w liście do ks. bpa Teofila Bromboszcza z dnia 28.10.1935 roku.

24 Zob. m.in. AAKat., ARZ, sygn. 47/413, Caritas, tom II (1934-1936), k. 323. Komunikat nr 1 w sprawie pomocy bezrobotnym z dnia 26.10.1936 roku; AAKat., ARZ, sygn.47/555, Towarzystwa i uroczystości świeckie, tom III (1937-1939), k. 101. „Polonia" z 27.11.1937 roku, k. 9; AAKat., AL, sygn. 46/2596, Żory. Ogólne, tom II (1931-1978), 
Pomimo szeregu zadrażnień społecznych najbardziej typową grupa inteligencji górnośląskiej, której starania stanowiły ważny, bo unifikacyjny czynnik, było właśnie duchowieństwo katolickie. Jego działania stały się szczególnie widoczne na wsi, gdzie duszpasterz stanowił zwykle jedyny autorytet. W miastach i ośrodkach przemysłowych rola duchowieństwa ulegała licznym modyfikacjom. Tam rysował się konflikt duchownego z nową, laicyzującą rzeczywistością polityczną, a czasem także społeczną. Duchowieństwo górnośląskie plebejskiego pochodzenia, emocjonalnie związane z grupami społecznymi, z których wyrosło, drażniło swoim zachowaniem szczególnie przybywających inteligentów. W warunkach określonych istnieniem polskiego państwa narodowego nie było już zapotrzebowania na duchownych jako specjalistów od organizacji polskiego życia. Rolę tę zaczęli przejmować działacze świeccy, najczęściej nauczyciele. Zarysowujący się konflikt pod rządami sanacji stał się rzeczywistością i wkrótce obóz ten stał się przeciwnikiem historycznie ukształtowanej pozycji Kościoła na polu wychowania. Nie pogodził się on z rolą Kościoła w kwestiach społecznych $^{25}$. Duchowny, będący dotąd ważnym czynnikiem integracji społecznej na wsi, stracił swój autorytet w mieście.

\section{Kwestia szkolna}

W szczególnej sytuacji na Górnym Śląsku znalazły się nauczycielki. W tradycji śląskiej praca zawodowa kobiet nie cieszyła się przychylnością rodzimej społeczności. Konserwatywnie nastawiony Górny Śląsk widział kobietę realizującą się jako matka i żona. Uważano, że podejmowanie przez kobietę pracy zawodowej zaburza ustalony porządek i powoduje upadek moralności kobiet, co może odbijać się negatywnie na funkcjonowaniu rodziny. Pejoratywne podejście społeczności śląskiej do pracy zawodowej kobiet spowodowało, że pracujące jako nauczycielki kobiety znalazły się w trudnej sytuacji, mimo że stanowiły zdecydowaną mniejszość stanu nauczycielskiego. Często nie znały gwary śląskiej, co istotnie utrudniało porozumiewanie się z uczniami. Wobec tego zaczęły pojawiać się prośby rodziców o zatrudnianie w szkołach nauczycieli, a nie

k. 96; AAKat., AL, sygn.46/2286, Tarnowskie Góry. Ogólne, tom II (1923-1940), k. 111, 164; AAKat., AL.,46/1564, Nowy Bytom. Ogólne. Tom II (1924-1978), k. 11; AAKat., AL, 46/379, Królewska Huta. Parafia św. Barbary. Obsadzenia, tom V (1928-1939), k. 167. J. Myszor, Historia diecezji katowickiej, Katowice 1999, s. 173.

E. Kopeć, My i oni..., op. cit., s. 61-62.

36 Folia Historica Cracoviensia, t. 24, z. 2 (2018) 
nauczycielek. Uważano ponadto, że przybyłe na Śląsk nauczycielki mają zły wpływ na młodzież. Dotyczyło to zwłaszcza nauczycielek po rozwodach. Jednak czynnikiem, który przesądził o niemożności wykonywania pracy zawodowej przez nauczycielki, było macierzyństwo. Uważano, że kobieta w ciąży powinna spędzać czas w domu, a nie pokazywać się publicznie. Z tego powodu do władz oświatowych wpływały skargi, w których podważano zasadność pracy nauczycielek-mężatek, a także ich wygląd i ubiór, a sam widok nauczycielki w błogosławionym stanie poczytywano za nieodpowiedni dla młodzieży. Przesłanki te spowodowały, że 29 marca 1926 roku Sejm Śląski przyjął Ustawę w sprawie rozwiązania służby nauczycielskiej wskutek zawarcia przez nauczycielkę związku małżeńskiego, potocznie nazwaną celibatową ${ }^{26}$. Nastąpiły wówczas masowe zwolnienia nauczycielek - tylko w sierpniu 1926 roku zwolniono 250 kobiet. Podczas debaty nad uchwaleniem ustawy podnoszono argumenty o wyższym koszcie zatrudnienia mężatki oraz o konieczności ułatwienia mężczyznom podejmowania pracy, co miało przyczynić się do uzdrowienia stosunków społecznych ${ }^{27}$. Pomimo protestów różnych środowisk opowiadających się za nadaniem kobietom śląskim pełni praw publicznych tzw. ustawa celibatowa została w 1933 roku zatwierdzona przez prezydenta Rzeczypospolitej. Prezydent uczynił tak ze względów politycznych, aby zyskać przychylność Ślązaków dla programu rządzącego Polską obozu sanacyjnego ${ }^{28}$. Kontrowersje społeczne dodatkowo zostały pogłębione przez konflikt na tle szkoły wyznaniowej.

W walce o wyznaniowy charakter szkoły Komisja Śląska ZPNSP, skupiająca w większości element napływowy, domagała się rozszerzenia szkolnych ustaw polskich na województwo śląskie oraz nadzoru Ministerstwa Wyznań Religijnych i Oświecenia Publicznego. W związku z tym postulatem ZPNSP wystąpił z propozycją wprowadzenia na Górnym Śląsku tylko dwóch godzin nauki religii (zamiast dotychczasowych pięciu), podobnie jak to było na mocy konkordatu w części cieszyńskiej Śląska i na

26 M. Urbańska, Nauczycielki województwa ślaskiego w czasie ustawy celibatowej (1926-1938), "Saeculum Christianum", nr 18/2 (2011), s. 171-173.

27 Ustawa z dnia 29 marca 1926 r. w sprawie rozwiązania stosunku służby nauczycielskiej wskutek zawarcia przez nauczycielkę związku małżeńskiego (Dziennik Ustaw Śląskich 1926, Nr 8, poz. 12). A. Glimos-Nadgórska, Polskie szkolnictwo powszechne województwa śląskiego (1922-1939), Katowice 2000, s. 183-184. M. Łysko, Udział kobiet $w$ życiu publicznym II Rzeczypospolitej Polskiej, "Miscellanea Historico-Iuridica", t. XIV (2015), z. 1, s. 391. 
pozostałych terenach Polski ${ }^{29}$. Decyzje związkowe wywołały burzę w środowisku konserwatywno-katolickim. Pojawiły się ataki w prasie, agitowano przeciwko związkowi w pociągach i tramwajach. Przedstawiono nauczycieli skupionych w ZPNSP jako demoralizatorów, wrogów narodu i religii. Sytuacja zaogniła się w marcu 1925 roku, kiedy Sejm Śląski uchwalił ustawę o zwalnianiu nauczycielek-mężatek bez znaczącej odprawy oraz prawa do emerytury, niezależnie od stażu pracy. Problem ten dotknął przeważnie przybyszy z innych dzielnic kraju, ponieważ to nauczyciele stanowili do 1939 roku najliczniejszą grupę zawodową wśród przybyłej inteligencji. W 1929 roku dominowali osiedleńcy z byłego zaboru austriackiego - 1290 osób, kolejne miejsce zajmował były zabór rosyjski - 284 osoby, następnie 84 osoby - były zabór pruski, natomiast 93 osoby to repatrianci. Kolejne zestawienie sporządzone w 1935 roku wykazało, że 2642 osoby pochodziły z innych dzielnic Polski, 1523 z województwa śląskiego, w tym 1064 Górnoślązaków i 459 pochodzących z cieszyńskiej części województwa ${ }^{30}$. Szerokim echem odbił się w prasie proces wytoczony przez kurię biskupią w Katowicach dwóm napływowym nauczycielkom z Kobióra. Indagowano je z powodu strojów zbyt śmiałych i określanych przez miejscową ludność jako nieprzyzwoite ${ }^{31}$.

W 1934 roku w Hajdukach Wielkich miał miejsce kolejny konflikt społeczny. Latem dzieci ze szkół powszechnych miały przyjąć I Komunię Świętą. W tym dniu przyszły wraz z rodzicami i nauczycielkami do kościoła. Na miejscu okazało się jednak, że wszystkie ławki zarezerwowane uprzednio dla nadzorujących dzieci nauczycielek były zajęte. Wobec zaistniałej sytuacji towarzyszące dzieciom nauczycielki stanęły obok ławek. Po chwili zbliżył się do nich kościelny i począł w obraźliwych słowach nawoływać je do opuszczenia zajmowanych miejsc i cofnięcia się w głąb kościoła. Na uwagę nauczycielek, że przybyły do kościoła nadzorować dzieci, kościelny odpowiedział hałaśliwą awanturą. W kościele powstało zamieszanie, skutkiem którego nauczycielki opuściły świątynię. Także obecna przy tym

29 J. Syska, Z walki o Śląsk i szkołe powszechna, Katowice 1975, s. 86, 99.

30 M. Wanatowicz, Ludność napływowa na Górnym Ślasku w latach 1922-1939, Katowice 1982 , s. $150-152$.

31 J. Syska, Z walki o Śląsk..., op. cit., s. 95-96. Zob. AAKat., ARZ, 47/2152, Wykaz nauczycieli, tom I (1932-1935), k. 148-156. W Kobiórze w szkole powszechnej na 12 zatrudnionych tam nauczycieli 7 legitymowało się pochodzeniem innym niż górnośląskie. 
wydarzeniu ludność przyjęła wobec nauczycielek wrogą postawę, bucząc i krzycząc w ich stronę. Celebrujący mszę św. ks. Józef Czempiel miał wówczas dodać, że kazanie jest skierowane także do nauczycielstwa, o ile "jest ono jeszcze w kościele obecne"32.

Na przestrzeni lat pojawiły się na Górnym Śląsku stowarzyszenia, których celem była obrona zagrożonych utratą pracy Górnoślązaków: Związek Rodowitych Ślązaków, Zrzeszenie Pisarzy Regionalnych "Silesia”, Stowarzyszenie Absolwentów Szkół Technicznych Górnoślązaków czy Związek Urzędników Pocztowców Górnoślązaków. Wszędzie tam, gdzie dominował bądź element napływowy, bądź miejscowy, dochodziło do trwałej dezintegracji konkretnego środowiska zawodowego. Zjawisko to z największym nasileniem występowało we wspomnianych już ruchach nauczycielskich ${ }^{33}$. Wyłoniło się w tym okresie również wiele problemów na płaszczyźnie organizacji życia kulturalnego. Liczne, ale ubogie w księgozbiór biblioteki, brak domów ludowych oraz odpowiednich lokali na czytelnie i świetlice stanowiły ogromną przeszkodę w pracy inteligencji z wykształceniem humanistycznym. Poszerzał się zakres pracy kulturalno-społeczno-oświatowej. Organizacji przedstawień teatralnych czy wycieczek do Warszawy i Krakowa podejmowała się napływowa grupa społeczna. Mimo ogromu pracy włożonego w rozwój życia kulturalnego inteligencji z byłej Galicji zyskali przydomek „Kulturträger". Napływ inteligencji o odmiennych potrzebach kulturowych, rozbieżnych gustach czytelniczych i wymaganiach estetycznych łamał miejscowe konwenanse myślowe i literackie, co prowadziło do różnicowania na lepszych i gorszych Polaków ${ }^{34}$. Do ostrych napięć dochodziło na tle języka, który przez długi czas był wyznacznikiem podziału na element napływowy i miejscowy. Inteligencja górnośląska starszego pokolenia posługiwała się gwarą, nie tylko w kontaktach z miejscową ludnością, lecz także w instytucjach życia publicznego. Na ten stan rzeczy ostro reagowała inteligencja napływowa, zwłaszcza z byłej Galicji. Miejscowa interpretacja języka polskiego stała się przedmiotem drwin ${ }^{35}$.

AAKat, AL, 46/2810, Chorzów-Batory. Hajduki (Bismarckhbtte). Parafia WNMP. Szkolnictwo, tom I (1924-1986), k. 4. Urząd Wojewódzki Śląski - Wydział Oświecenia Publicznego do Kurii Biskupiej z dnia 2 czerwca 1934 roku.

33 M. Wanatowicz, Inteligencja na Ślasku..., op. cit., s. 101.

34 M. Wanatowicz, Inteligencja na Śląsku..., op. cit., s. 89. "Kulturtrgger" - określenie oznaczające osobę uzurpującą sobie prawo do narzucania innym społeczeństwom swoich zasad i kultury; spopularyzował je separatystyczny ruch Kustosa. M. Wanatowicz, Inteligencja na Śląsku..., op. cit., s. 90. 
Czynnikiem dezintegracji był również aspekt polityczny. Przewaga autochtonów wśród nurtów chrześcijańsko-narodowych oraz związek przeważającej części napływowej inteligencji (w tym nauczycieli) z sanacją prowadziły do powstania dwóch przeciwstawnych grup. Podziały dzielnicowe dostarczały animozji na tle odmiennej taktyki, sposobu myślenia politycznego. „Polak" w numerze 208 z 1922 roku pisze:

Inteligencja jest obłudna i bezbożna. Inteligencja, która napłynęła na Górny Śląsk w ostatnim czasie jest taka, jaką nam przysłał rząd warszawski, a ten nie jest endecko-chadecki, dlatego inteligencja przybyła też nie jest taka. Co do inteligencji górnośląskiej, ta zawsze stała na gruncie chrześcijańskim. Przedstawiciele tej inteligencji w zjeździe brali udział o ile to było potrzebne. Cała zaś inteligencja śląska, ani nie była tam potrzebna ani nie mogła być tam obecna. Zresztą ani samo duchowieństwo nie było tam w komplecie $^{36}$.

\section{Polsko-niemieckie napięcia narodowościowe}

Integrację społeczną znacznie utrudniały pomówienia kierowane wobec przybywającej na ten teren inteligencji polskiej podnoszone przez propagandę niemiecką. Wykorzystywała ona w tym celu prasę, trybunę sejmową i plotkę. W częstych wystąpieniach przeciw nauczycielstwu polskiemu przodował Thomas Szczeponik, przywódca Deutsche Katholische Volkspartei. W jego wystąpieniach zawsze chodziło o skompromitowanie w opinii górnośląskiej ludności autochtonicznej tych funkcjonariuszy, którzy byli mocno związani z szerzeniem polskiej ideologii ${ }^{37}$. Wzrastające naprężenie polsko-niemieckie nie mogło pozostać bez wpływu na stosunki wśród lekarzy, zwłaszcza że liczba lekarzy Polaków osiedlonych na Śląsku wzrosła z 25 do 96, a liczba lekarzy Niemców spadała z 257 do $200^{38}$. Natomiast stosunek imigrantów z Polski do Niemców był bardziej bezkompromisowy niż ogółu miejscowej inteligencji. Inteligencja napływowa już przed rokiem 1926, a następnie w okresie rządów sanacji, była głównym inspiratorem różnorodnych działań zmierzających do osłabienia wpływów niemieckich.

Zob. też. "Goniec Śląski" z 21.09.1922 roku; Zjazd katolicki a inteligencja i jeszcze coś więcej.

37 E. Kopeć, My i oni..., op. cit., s. 59-60.

38 E. Hanke, Trudy i oczekiwania. Wspomnienia lekarza, Warszawa 1965, s. 167. 
Konflikt w tym ostatnim okresie był przez Polaków coraz mocniej eksponowany, przez co przysłaniał kwestie społeczne. Organizacje skupiające przedstawicieli obu grup narodowościowych były niezmierną rzadkością. Wymownym przykładem zaognienia stosunków było zerwanie kontaktów zawodowych z dziennikarzami niemieckimi przez Syndykat Dziennikarzy Śląska i Zagłębia Dąbrowskiego w 1937 roku jako reakcja na prześladowanie prasy polskiej w Niemczech ${ }^{39}$.

\section{Pomiędzy integracją a regionalizmem}

Po serii społecznych tarć odpowiedzialność za integrację społeczeństwa górnośląskiego wzięły na siebie władze wojewódzkie, które starały się zachęcić inteligencję z innych regionów do dobrowolnego osiedlania się na Górnym Śląsku. W tym celu zmieniły przepisy dotyczące zwrotu kosztów przesiedlania się, zrównując w prawach pracowników służbowo przenoszonych i na własną prośbę. Stąd w mowie budżetowej ze stycznia 1937 roku wojewoda Michał Grażyński wyraził następującą opinię o nauczycielstwie:

Chcę stwierdzić z całym poczuciem odpowiedzialności, że tutejsze nauczycielstwo tak w szkole, jak i poza szkołą wypełnia dobrze swoje obowiązki, i że praca jego łączy się jak najściślej z tymi zasadami wychowawczymi oraz z tymi ideałami narodowymi i państwowymi, które tworzą wytyczną dla uczciwej pracy obywatelskiej. Uważam za swój obowiązek w tej Izbie wypowiedzieć swój pogląd na temat wartości i pracy nauczyciela na Śląsku po to, aby odeprzeć w sposób nie budzący wątpliwości te ataki, które zmierzały do uszczuplenia jego zasług patriotycznych i do poderwania tego zaufania, którym powinien cieszyć się w polskim społeczeństwie ${ }^{40}$.

Sytuacja historyczna ziem polskich ukształtowała w społeczeństwie polskim różne modele obyczajowe. Dlatego inteligencję pracującą na Górnym Śląsku cechowały odmienne sposoby bycia, zwyczaje towarzyskie, ubiory, typy wyobraźni i umysłowości, mentalność. Utrudniały one nawiązywanie kontaktów, wpływały na tworzenie się inteligenckich gett dzielnicowych ${ }^{41}$.

M. Wanatowicz, Inteligencja na Śląsku..., op. cit., s. 96-98.

"Ogniskowiec" nr 3/4, 1937/1938, s. 53.

M. Wanatowicz, Inteligencja na Śląsku..., op. cit., s. 92. 
Imigrantów przybyłych na Górny Śląsk raziły labilne postawy narodowe, zauważalne głównie wśród dużej grupy inteligencji górnośląskiej, która wywodziła się nie tylko z klas plebejskich, lecz także spośród inteligencji. Po I wojnie światowej wśród pracowników umysłowych i inteligencji istniała grupa określająca się jako neutralna pod względem postaw narodowych, przewyższająca liczebnie nastawioną propolsko ludność. Taki indyferentyzm narodowy stanowił cechę pogranicza etnicznego i był niezależny od statusu społecznego.

Wykorzystywanie w walce politycznej stereotypów odnoszących się do Górnego Śląska i jego mieszkańców wzmagało negatywne opinie o „obcych" przybywających na ten obszar. Najmniejsze różnice występowały pomiędzy Górnoślązakami, Wielkopolanami i Pomorzanami, więc w grupie pochodzącej z tego samego zaboru. Imigranci odegrali ogromną rolę w rozwoju ruchu polskiego w tej dzielnicy, następnie brali czynny udział w walce powstańczej i plebiscytowej. Przybysze z ziem zaboru pruskiego w okresie międzywojennym uważali się za napływowych autochtonów, a ich potomkowie czuli się Górnoślązakami. Ich napływ był wówczas niewielki, mniejszy niż przed wojną, co wynikało z potrzeb kadrowych Pomorza i Wielkopolski ${ }^{42}$. Poczucie wyższości cywilizacyjnej i gospodarczej oraz pogarda dla niżej stojących pod tym względem Galicjan i Kongresowiaków spowodowało, że ci ostatni w momencie przyjazdu na Górny Śląsk zostali poddani ocenie przez pryzmat uprzedzeń. Dodatkowo przekonanie o specyficznych cechach oblicza kulturowego, szczelnie separujących ten obszar od wpływów świata zewnętrznego, utrwalane było również w konsekwencji stykania się miejscowych mieszkańców z odmiennymi postawami prezentowanymi przez osoby napływające na Górny Śląsk ${ }^{43}$. Rozważając problem napływu, M. Wanatowicz dochodzi do konkluzji, że na terenie Górnego Śląska napływ oscylował w granicach maksymalnie do 40-50 tys., 5 tys. liczyły administracja wojewódzka, ogólnopaństwowa i kolej, 5 tys. szkolnictwo i instytucje kulturalne, około 1000 służba zdrowia i sądownictwo, około 1500 służba policyjna, do tysiąca drobnomieszczaństwo, do 2000 inżynierowie, technicy, pracownicy administracji przemysłu, do 10 tys. robotnicy, do 6000 stacjonujące wojsko. W sumie daje to liczbę 31500 osób. Przewagę mieli samotni imigranci. Jednak wliczając w to rodziny przybyszy, nie była to liczba większa niż kilkanaście

42 M. Wanatowicz, Inteligencja na Śląsku..., op. cit., s. 77-78.

43 L. Krzyżanowski, Ruchy migracyjne..., op. cit., s. 276-277. 
tysięcy ${ }^{44}$. Imigranci z innych dzielnic Polski stanowili na Górnym Śląsku 4-5\% ogółu ludności ${ }^{45}$. Niemniej jednak różnice wypływające z pochodzenia dzielnicowego, narodowościowego czy wyznania utrwalały funkcjonujące stereotypy, które zniekształcały obraz społeczeństwa. Obok faktycznych odrębności pojawiały się i fikcyjne, tworząc skuteczną barierę w kontaktach. Stereotyp przybysza-",gorola" z Galicji był eksponowany najmocniej. Antagonizmy dzielnicowe ujawniały się przez cały omawiany okres. Ich źródło stanowiły rywalizacja ekonomiczna, walka polityczna, różne modele cywilizacyjno-kulturowe. Widoczne na wszelkich płaszczyznach życia publicznego, od izolacji towarzyskiej do otwartej walki, podczas której posługiwano się stereotypami, oszczerstwami, impertynencjami. Wiele sporów wymagało interwencji władz wojewódzkich, sądów lub rozwiązywano je poprzez pojedynki i rękoczyny.

Zakres postaw przyjmowanych przez ludność napływową w stosunku do rodzimej społeczności Górnego Śląska był rozległy ${ }^{46}$. Od akceptacji i współpracy, po zupełne wykluczenie przybyszy poza nawias życia towarzyskiego. Wzajemne kontakty na płaszczyźnie życia rodzinnego, w organizacjach społecznych, zawodowych i politycznych, w Kościele, wszystko to prowadziło napływową ludność do refleksji, że jej zachowanie, obyczajowość, światopogląd, są dalekie od postaw Górnoślązaków, którym bliżej było do niemieckich mieszkańców tego terenu. Liczba napływowych, głównie inteligencji, nie była jednak tak duża, jak już wcześniej sygnalizowano, żeby wyjaskrawiać spory z autochtonami, niemniej jednak, z racji sprawowanych funkcji przez inteligencję, stała się ona obiektem do obserwacji ze strony władz i społeczeństwa. Istotnie napływowi zdawali sobie sprawę, że stanowią konkurencję do stanowisk pracowniczych, dlatego oceny wobec nich wynikały w zasadzie z pryzmatu jego konkurencyjnych aspiracji zawodowych. Jakkolwiek aspekt ekonomiczny był fundamentalny, to odmienność obyczajowa napływowych stała się nie mniej ważnym elementem w sporze. Prezentowane tu wzajemne inkryminacje niezbicie dowodzą istnienia istotnych różnic dzielących środowiska napływowych i miejscowych.

44 M. Wanatowicz, Ludność napływowa na Górnym Śląsku..., op. cit., s. 169.

45 M. Wanatowicz, Województwo ślaskie (1922-1939), w: J. Bahlcke, D. Gawrecki, R. Kaczmarek (red.), Historia Górnego Śląska. Polityka, gospodarka i kultura europejskiego regionu, Gliwice 2011, s. 239.

L. Krzyżanowski, Ruchy migracyjne..., op. cit., s. 278.

Joanna Karabin, Problemy integracyjne ludności napływowej... 


\section{Podsumowanie}

Pomimo szeregu kontrowersji będących udziałem środowiska górnośląskiego należy niewątpliwie zauważyć, że podejmowane były wysiłki zmierzające do roztoczenia opieki nad ludnością przybyłą na Górny Śląsk. Zarówno społeczność rodzima, jak i władze świeckie i religijne nadawały przybyszom pozycje społeczne odpowiadające ich roli, wprowadzając zarazem w pełni zasady demokratycznego współżycia w środowiskach autochtoniczno-napływowych. W ten sposób, dzięki wspólnym przedsięwzięciom, także w świadomości ludności rodzimej ugruntowało się przekonanie, że stanowi ona nierozerwalną cząstkę narodu polskiego. 


\section{Bibliografia}

Źródła

1. Archiwum Archidiecezjalne w Katowicach, Akta Lokalne:

Chorzów-Batory. Hajduki (Bismarckhbtte). Parafia WNMP. Szkolnictwo.

Tom I (1924-1986).

Chorzów. Parafia św. Jadwigi. Tom II (1935-1978).

Królewska Huta. Parafia św. Barbary. Obsadzenia. Tom V (1928-1939).

Nowy Bytom. Ogólne. Tom II (1924-1978).

Tarnowskie Góry. Ogólne. Tom II (1923-1940).

Żory. Ogólne. Tom II (1931-1978).

2. Archiwum Archidiecezjalne w Katowicach, Akta Rzeczowe:

Akcja Katolicka. Tom I (1932-1936).

Caritas. Tom II (1934-1936).

I Śląski Zjazd Katolicki (1922).

Synod. Tom I (1928-1935).

Towarzystwa i uroczystości świeckie. Tom III (1937-1939).

Wykaz nauczycieli. Tom I (1932-1935).

Prasa

"Goniec Śląski"

"Katolik"

"Ogniskowiec"

"Polak"

"Polonia"

\section{Opracowania}

Aleksa L., Inteligencja na Śląsku, Katowice 1975.

Glimos-Nadgórska A., Polskie szkolnictwo powszechne województwa śląskiego (1922-1939), Katowice 2000. 
Hanke E., Trudy i oczekiwania. Wspomnienia lekarza, Warszawa 1965.

Jaśkowiak F., Województwo poznańskie. Szkic monograficzny, Poznań 1980.

Łysko M., Udział kobiet w życiu publicznym II Rzeczypospolitej Polskiej, "Miscellanea Historico-Iuridica", t. XIV, z. 1 (2015), https://www.doi. org/10.15290/mhi.2015.14.01.23.

Myszor J., Historia diecezji katowickiej, Katowice 1999.

Kopeć E., "My i oni"na polskim Śląsku (1918-1939), Katowice 1986.

Krzyżanowski L., Ruchy migracyjne na Górnym Śląsku w XIX i w pierwszej połowie XX wieku a wielokulturowość tego obszaru w okresie międzywojennym, w: Procesy migracyjne: teoria, ewolucja i współczesność, red. L. Kacprzak, J. Knopek, Piła 2008.

Krzyżanowski L., Spór o postawę religijna międzywojennej inteligencji na polskim Górnym Śląsku. Casus Tadeusza Starka „Folia Historica Cracoviensia", t. 3, nr 7 (2016).

Pachoński J., Pomoc Krakowa dla Górnego Śląska w okresie powstań (1919-1921), Nauka dla wszystkich (PAN), t. 346, Wrocław 1981.

Popiołek K., Historia Śląska. Od pradziejów do 1945 roku, Katowice 1972. Rybicki P., O badaniu socjograficznym Ślaska, Katowice 1938.

Szramek E., Śląsk jako problem socjologiczny. Próba analizy, Katowice 1934.

Syska J., Z walki o Śląsk i szkołę powszechna. Wspomnienia z lat 1918-1939, Katowice 1975.

Tokarska A., Książki, ludzie, idee. Kontakty kulturalne Górnego Śląska z Krakowem w dobie niewoli narodowej, Katowice 2003.

Trąba M., Ksiądz dr Teodor Kubina. Działalność społeczna i narodowa w latach 1905-1925, Świętochłowice 2002.

Urbańska M., Nauczycielki województwa śląskiego w czasie ustawy celibatowej (1926-1938), "Saeculum Christianum", r. 18, nr 2 (2011).

Wanatowicz M., Inteligencja na Śląsku w okresie międzywojennym, Katowice 1986.

Wanatowicz M., Ludność napływowa na Górnym Śląsku w latach 1922-1939, Katowice 1982.

Wanatowicz M., Województwo śląskie (1922-1939), w: Historia Górnego Śląska. Polityka, gospodarka i kultura europejskiego regionu, red. J. Bahlcke, D. Gawrecki, R. Kaczmarek, Gliwice 2011. 


\section{Abstrakt}

Joanna Karabin

Problemy integracyjne ludności napływowej na polskim Górnym Śląsku w okresie dwudziestolecia międzywojennego

Celem publikacji jest przedstawienie trudności związanych z asymilacją ludności przybywającej z innych regionów kraju na polski Górny Śląsk w okresie międzywojennym. Problemy migrantów zaznaczały się niemal na każdej płaszczyźnie życia publicznego, w szczególności ideologicznej, społecznej i państwowej. Miało to związek z dwoma modelami integracji występującymi na polskim Górnym Śląsku. Pierwszy, reprezentowany przez element napływowy, kierujący się przede wszystkim racjami ogólnokrajowymi, kolidował ze schematem uznającym za podmiot wszystkich działań na Górnym Śląsku wyłącznie społeczność autochtoniczną. Owa odmienność znacznie utrudniała wypracowanie spójnej tożsamości, a co za tym idzie, generowała szereg innych antagonizmów skutkujących atmosferą niechęci lub nawet wrogości; przykładem był długofalowy konflikt pomiędzy nauczycielstwem napływowym a Kościołem katolickim. Jednakże wszelkie niepowodzenia integracji na płaszczyźnie państwowej rekompensowane były przez sukcesy w dziele integracji społecznej i związanym z nią aspektem demograficznym.

Słowa kluczowe: Górny Śląsk, inteligencja, migracja, integracja, Kościół katolicki 


\title{
Abstract
}

\author{
Joanna Karabin \\ Integration Problems of Immigrants in Polish Upper Silesia during the Interwar \\ Period
}

Keywords:

Upper Silesia, intelligence, migration, integration, Catholic Church
The text of this article includes the issue of social integrity of the inflow population from other districts of Poland in the area of the Prussia Upper Silesia, included into the Polish state on the map. The chronological frames are indicated with the time of existence of the II Republic of Poland. The aspect of social integrity covered the issues connected with process of including different social groups with into Upper Silesia society and as a result of obtaining the possibilities, rights and services by them available only for local population. This process was not an obvious thing as it often meant the necessity to waive its identity by one or both parties understood as values, standards, traditions, customs, right, views, even the language. A complex process of social integritywas one of the most distinctive difficulties in this region.

Folia Historica Cracoviensia, t. 24, z. 2 (2018) 